\title{
Parotid MR Sialography, Can it Help in Patients with Hepatitis C Virus Related Sicca Syndrome?
}

\author{
AHMED A. MAHMOUD, M.D.; MOHAMMED H. KAMEL, M.D. and MEDHAT M. MADBOULY, M.D. \\ The Department of Radiology, Theodor Bilharz Research Institute, Cairo, Egypt
}

\begin{abstract}
Background: The Hepatitis C Virus (HCV) related sicca syndrome occurs in association with $\mathrm{HCV}$ infection in a range of $4-57 \%$. Salivary gland chronic inflammation and B cell proliferation is triggered by HCV. MR sialography is a noninvasive method for salivary glands complex duct system combined with their parenchymal evaluation through conventional MR T2 images and source images.

Aim of Study: To identify changes in parotid magnetic resonance sialography (MR Sialography) in HCV related sicca syndrome patients.

Patients and Methods: Prospective study included 64 HCV related sicca syndrome patients ( 38 female, 26 male, mean age $44.6 \pm 10.5$ years). All patients had performed parotid MR sialography. Severity of the disease was correlated with presence or absence of vasculitis and HCV disease duration.

Results: MR sialography changes were found in $25 \%$ of patients, (12/32 and 4/32 in patients with and without vasculitis, respectively). Among patients with vasculitis, those with abnormal MR sialography had longer disease duration along with more severe form of the disease.

Conclusion: Amongst HCV patients with vasculitis and longer disease duration, abnormal changes are identified on MR sialography.
\end{abstract}

Key Words: $H C V$-related sicca syndrome $-H C V$-related vasculitis - Magnetic resonance sialography.

\section{Introduction}

THE HCV related sicca syndrome occurs in association with $\mathrm{HCV}$ infection in a range of $4-57 \%$. Salivary gland chronic inflammation and $\mathrm{B}$ cell proliferation is triggered by $\mathrm{HCV}$ as it is a known sialotropic [1]. The exact pathogenesis of HCV related sicca syndrome is not yet established, however, it is postulated to be caused by host

Correspondence to: Dr. Ahmed A. Mahmoud, The Department of Radiology, Theodor Bilharz Research Institute, Cairo, Egypt immune-mediated mechanism, rather than direct viral effect [2] .

MR Sialography is a noninvasive method for salivary glands complex duct system combined with their parenchymal evaluation through conventional MR T2 images and source images. Normal peripheral ducts and acini indicate that the gland has not been completely destroyed. Ducts and acini stenosis, dilatations and cystic changes indicate destruction and compression $[3,4]$.

Objective: To identify parotid gland HCV related sicca changes using MR Sialography.

\section{Patients and Methods}

\section{Patients:}

This prospective study was performed in a private radiology center throughout February 2018 to January 2019. The study included 64 patients (mean age $45.8 \pm 10.8$ years) presented with positive $\mathrm{HCV}$ infection (26 males, 38 females) and sicca manifestation of xerostomia, the disease course range was recorded. The patients were referred from gastroenterologists and rheumatologists, and were divided into two groups, using the preliminary classification criteria for proposed by initial laboratory testing to assess presence of vasculitis. Informed consent was obtained from patients for all investigations. The protocol for the research project was approved by a suitably constituted Ethics Committee of the institution within which the work was carried out, conforming with requirements of the World Medical Association's Declaration of Helsinki. Inclusion criteria was $\mathrm{HCV}$ infection with sicca syndrome manifestations, exclusion criteria any contraindication for MR sialography as pacemaker or dental ferromagnetic prothesis. 


\section{Parotid MR Sialography acquisition:}

MR Sialography was performed on a 1.5-Tesla with a phased-array coil for neck. Lemon juice ingestion was used to stimulate salivation on MRI table before the exam beginning, to enhance the conception of the ductal system. Initially, a singleshot RARE sequence was obtained in the axial plane with parameters as follows: echo space 11.5 msec, TReff 1200 , section thickness $30-40 \mathrm{~mm}$, Field of View (FOV) 200mm, matrix 256, number of acquisitions one, and acquisition time $6 \mathrm{sec}$. On axial image used as a localizer, the oblique sagittal image plane was determined along presumed course of parotid duct. Source images were fast spin echo sequence using the following parameters: 9500/ 259/4 (TR/TReff/excitations), number of echoes for each excitation 27 , section thickness $2 \mathrm{~mm}$ with no intersection gap, number of sections acquired 18, FOV 170mm, matrix 2903 512, and acquisition time $6 \mathrm{~min} 45 \mathrm{sec}$. A fat-sat sequence was also obtained. Finally, Maximum Intensity Projection (MIP) reconstruction was generated.

\section{MR sialography interpretation:}

According to the criteria of X-ray sialography proposed by Rubin and Holt, MR sialographic stages were defined after reviewing MIP images and source images for parenchymal evaluation by a radiology consultant, blinded to the results of laboratory testing with 20 years' experience in GIT imaging.

- Stage 0: Normal.

- Stage 1: Punctuate; this is the earliest stage, in which diffuse, spherical areas of high signal intensity, $1 \mathrm{~mm}$ or less in diameter and uniform in size, are distributed evenly throughout the gland.

- Stage 2: Globular; in this stage of the disease, the spherical areas of high signal intensity increase to $1-2 \mathrm{~mm}$ in diameter.

- Stage 3: Cavitary; with further disease progression, the areas of high signal intensity coalesce and enlarge further, up to $1 \mathrm{~cm}$ in diameter, becoming irregular in size and distribution and decreasing in number.

- Stage 4: Destructive; this represents the end stage of the disease, in which there is a marked dilatation of the main duct with an irregular diameter [5].

\section{Statistical analysis:}

MR sialography staging of the cases was performed by the reviewer who was Statistical methods Statistical analysis was performed by SPSS (Ver- sion 11: SPSS Inc., Chicago, Il, USA) for Windows. The means and Standard Deviation (SD) were computed for the continuous variables; the difference between the means was tested by standard $t$ For comparison of percentages chi-squared (v2) was used. Differences were considered to be significant when $p$-value was $<0.05$.

\section{Results}

Forty eight patients with HCV $(75 \%)$ had normal glands (stage 0) Fig. (1). Sixteen patients $(25 \%)$ had abnormal findings (stages 1, 2, 4). Six out of sixteen patients $(37.5 \%)$ the glands had a punctuate appearance (stage 1) Fig. (2). Other six patients $(37.5 \%)$ had a globular appearance (stage 2) Fig. (3) and four patients (25\%) had a destructive appearance (stage 4) Fig. (4) (Table 1).

In group 1, vasculitis was the presenting symptoms of $\mathrm{HCV}$ in $28 / 32$ patients $(87.5 \%$ ), while the remaining had other $\mathrm{HCV}$ manifestations with no vasculitis manifestations (subclinical) (12.5\%).

By comparing the MR sialography findings of the patients with $\mathrm{HCV}$-associated vasculitis (group 1) and HCV patients without vasculitis (group 2), twelve patients from sixteen abnormal findings were from group $1(75 \%)$ compared to four out of sixteen were from group $2(25 \%)(p=0.22)$. The details of the MR results in group 1 and group 2 are shown in (Table 2).

Table (1): Demonstrates MR sialography different stages of the diseases.

\begin{tabular}{lcc}
\hline & $\begin{array}{c}\text { Patients } \\
\text { with HCV }\end{array}$ & Percentage \\
\hline Stage 0: No abnormality & 48 & $75 \%$ \\
Stages 1-4: & 16 & $25 \%$ \\
(Abnormal MR sialography) & & \\
\hline Total & 64 & $100 \%$ \\
\hline
\end{tabular}

Table (2): Comparing the MR sialography findings of the patients with $\mathrm{HCV}$-associated vasculitis (group 1) and $\mathrm{HCV}$ patients without vasculitis (group 2).

\begin{tabular}{lcc}
$\begin{array}{l}\text { Abnormal } \\
\text { MR } \\
\text { sialography }\end{array}$ & $\begin{array}{c}\text { Group 1 } \\
\text { with vasculitis } \\
(\mathrm{n}=32)\end{array}$ & $\begin{array}{c}\text { Group 2 } \\
\text { without vasculitis } \\
(\mathrm{n}=32)\end{array}$ \\
\hline Stage 0 & $20(62.5 \%)$ & $28(87.5 \%)$ \\
Stage 1 & $2 \quad(6.25 \%)$ & $4 \quad(12.5 \%)$ \\
Stage 2 & $6 \quad(18.75 \%)$ & \multicolumn{2}{c}{0} \\
Stage 3 & 0 & \multicolumn{2}{c}{0} \\
Stage 4 & $4 \quad(12.5 \%)$ & \multicolumn{2}{c}{0} \\
\hline Total & $32(100 \%)$ & \multicolumn{2}{c}{$32(100 \%)$} \\
\hline
\end{tabular}




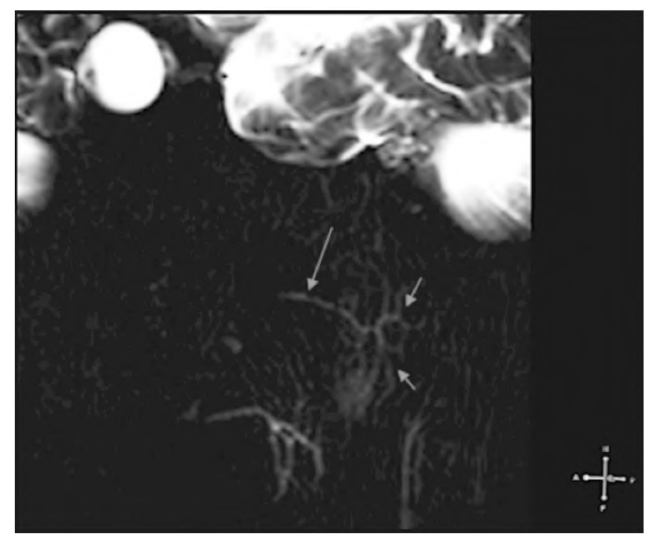

Fig. (1): 50 years male patient HCV positive with dry mouth, MR sialography MIP processed image oblique sagittal plane, after lemon juice stimulation ingestion shows uniform thin outline of parotid main duct (long arrow) and thin regular branching of parotid first and second order branches (short arrows) (normal)

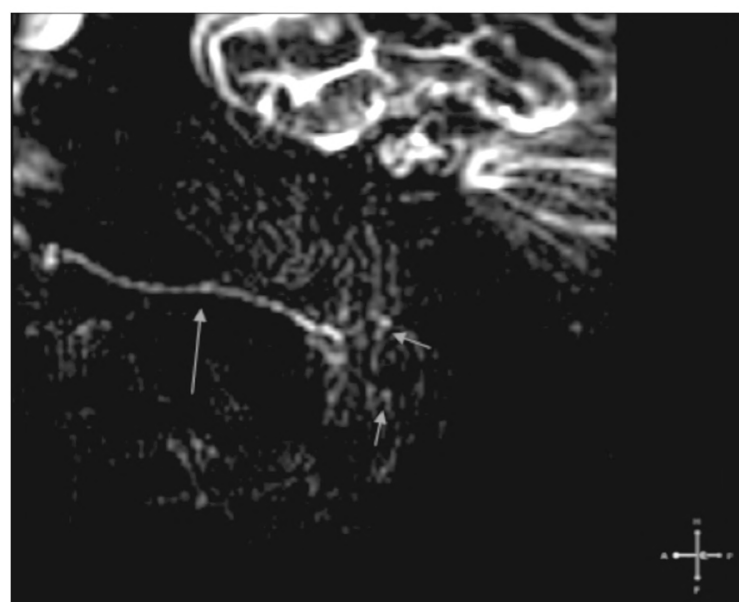

Fig. (3): 43 male patient HCV positive with sicca syndrome manifestations, MR sialography MIP image oblique sagittal plane, after lemon juice stimulation ingestion shows mild irregularity of parotid main duct (long arrow) and few multiple globular destructive lesions (short arrows) (stage 3).

\section{Discussion}

The frequent association between sicca syndrome and $\mathrm{HCV}$ infection has been demonstrated by both experimental and epidemiological studies focusing on the presence of chronic lymphocytic sialadenitis in patients with HCV infection [6]

In this study, among MR sialography of 64 $\mathrm{HCV}$ patients, abnormal MR sialography findings were identified in sixteen HCV patients $(25 \%)$. $\mathrm{HCV}$-related sicca syndrome previously reported to range from $4 \%$ to $57 \%$. This wide range is likely due to variances in diagnostic criteria [2].

In the current study, group (1) had HCVassociated vasculitis and group (2) had HCV in-

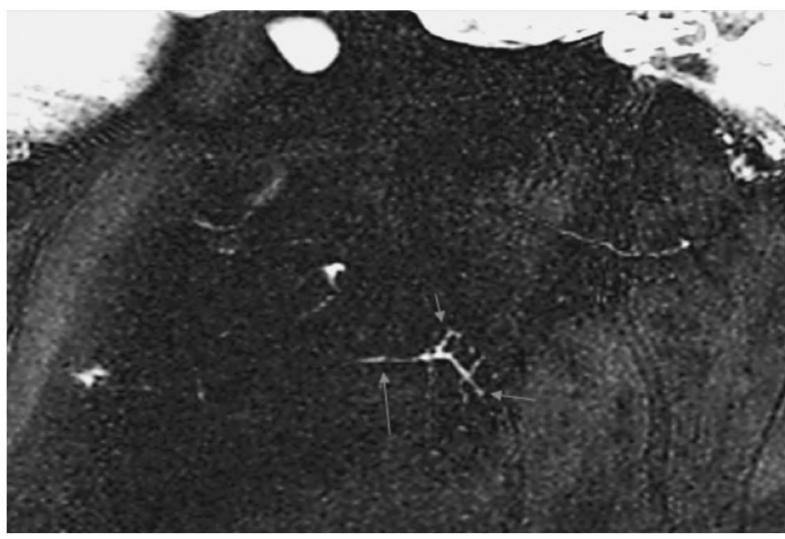

Fig. (2): 40 years male patient HCV positive with dry mouth, MR sialography MIP processed image oblique sagittal plane, after lemon juice stimulation ingestion shows minimal irregularity of parotid main duct (long arrow) and few tiny punctate lesions (short arrows) (stage 1).

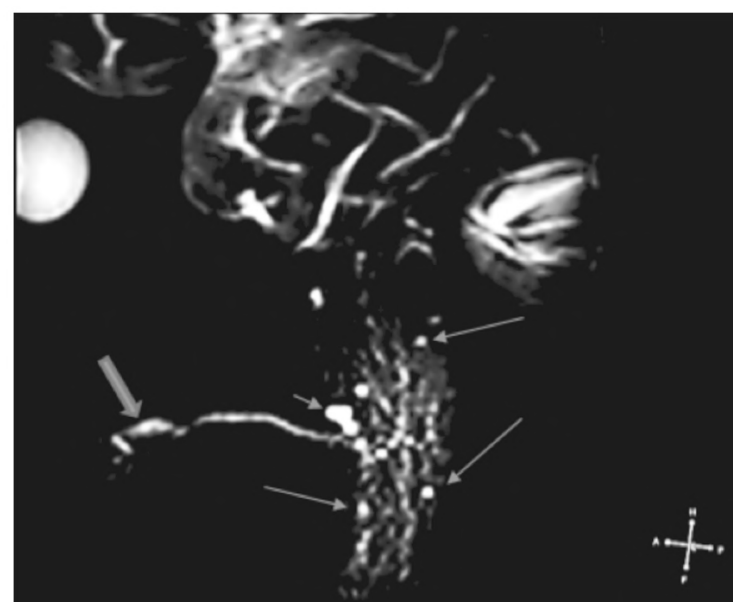

Fig. (4): 38 female patient HCV positive with dry mouth, MR sialography MIP processed image oblique sagittal plane, after lemon juice stimulation ingestion shows multiple globular (long arrow) and one large cavitary destructive lesion (short arrows) with associated dilatation and irregularity of parotid duct (thick arrow) (stage 4)

fection without any other extrahepatic manifestation other than sicca. When MR sialography findings of both groups were compared, twelve patients from group (1) had abnormal MRS findings compared to four patients in group (2). Higher destructive changes were noticed more in group (1) than in group (2), which only showed affection by stage (1).

Ren et al., [3] showed that Forty-four out of ninety-three patients (47.3\%) had diffusive globular appearance stage (2), which suggested that diffusive globular appearance is most common type of ducts dilation in Sjogren syndrome patients' $[\mathbf{7 , 8 ]}$.

T2-3D-DRIVE MR sialography is capable of depicting the subtle changes that take place in the 
parotid gland ducts of patients with SS; while MRI imaging is capable of detecting the diffusive fat deposit in parotid gland. Two MR techniques, when combined, can most effectively diagnose SS; and serve as a valuable supplementary tool for the traditional X-ray sialography examination $[9,10]$.

In this study, sicca syndrome showed stage (1) $\&$ stage (2) comprising (75\%), each stage representing $(37.5 \%)$.

Patients with HCV-associated vasculitis and MR sialography positive findings had a longer disease duration $(p<0.01)$.

This study has shown that MR sialography is capable of depicting the subtle changes that take place in the parotid gland ducts of patients with sicca syndrome.

\section{Conclusion:}

Abnormal changes on MR sialography are identified more amongst the HCV patients with vasculitis and longer disease duration.

\section{References}

1- JACOBSON M., CACOUB P., DAL MASO L., HARRISON S.A. and YOUNOSSI Z.M.: Manifestations of chronic hepatitis $\mathrm{C}$ virus infection beyond the liver. Clin. Gastroenterol. Hepatol., 8: 1017-29, 2010.

2- NAWITO Z., AMR AMIN A., ABU EL-FADL S. and ABU EL EINEN K.: Sicca complex among Egyptian patients with chronic hepatitis $\mathrm{C}$ virus infection. Clin. Rheumatol., 30: 1299-304, 2011.

3- REN Y., LI X., ZHANG J., LONG L., LI W. and HAN Y.: Conventional MRI techniques combined with MR sialography on T2-3D-DRIVE in Sjögren syndrome Int. J. Clin. Exp. Med., 8 (3): 3974-82, 2015.
4- OGURA I., SASAKI Y., ODA T., SUE M. and HAYAMA K.: Magnetic Resonance Sialography and Salivary Gland Scintigraphy of Parotid Glands in Sjögren's Syndrome. Chin. J. Dent. Res., 21 (1): 63-8. doi: 10.3290/j.cjdr. a39919, 2018.

5- LIU S., CHEN W., WANG M., WU T., DONG L., PAN C. and ZHU W.: Quantitative Analysis of Parotid Gland Secretion Function in Sjögren's Syndrome Patients with Dynamic Magnetic Resonance Sialography. Korean J. Radiol., 20 (3): 498-504. doi: 10.3348/kjr.2018.0508, 2019.

6- WANG Y.1, DOU H., LIU G., YU L., CHEN S., MIN Y., ZHAO K., WANG X. and HU C.: Hepatitis C virus infection and the risk of Sjögren or sicca syndrome: A meta-analysis. Microbiol. Immunol., 58 (12): 675-87. doi: 10.1111/1348-0421.12202, 2014.

7- KOCH M. and IRO H.: Salivary duct stenosis: Diagnosis and treatment. Acta Otorhinolaryngol. Ital., 37 (2): 132141. doi: 10.14639/0392-100X-1603, 2017.

8- YOKOSAWA M., TSUBOI H., NASU K., HAGIYA C., HAGIWARA S., HIROTA T., EBE H., TAKAHASHI H., ASASHIMA H., 9. KONDO Y., OGISHIMA H., SUZUKI T., MINAMI M., BUKAWA H., MATSUMOTO I. and SUMIDA T.: Usefulness of MR imaging of the parotid glands in patients with secondary Sjögren's syndrome associated with rheumatoid arthritis. Mod. Rheumatol., 25 (3): 415-20, 2015

9- NIEMELÄ R.K., TAKALO R., PÄÄKKÖ E., SURAMO I., PÄIVÄNSALO M., SALO T. and HAKALA M.: Ultrasonography of salivary glands in primary Sjögren's syndrome. A comparison with magnetic resonance imaging and magnetic resonance sialography of parotid glands. Rheumatology, 43 (7): 875-9, 2004.

10- GADODIA A., BHALLA A.S., SHARMA R., THAKAR A. and PARSHAD R.: MR sialography of iatrogenic sialocele: Comparison with conventional sialography. Dentomaxillofac. Radiol., 40 (3): 147-53. doi: 10.1259/ dmfr/32834129, 2011. 


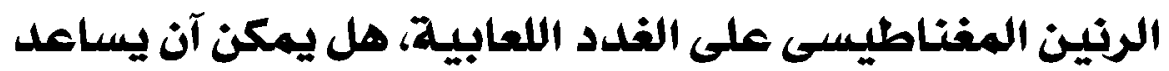

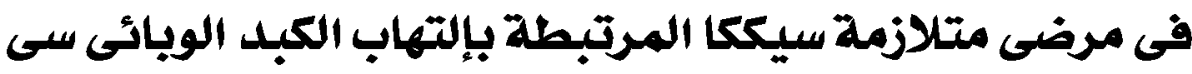

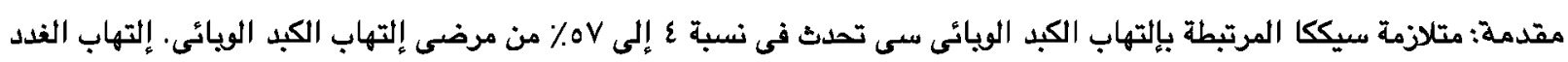

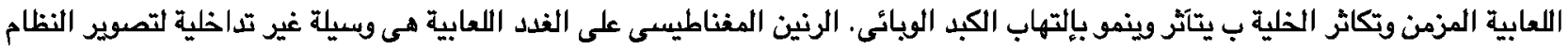

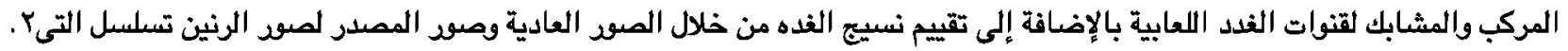
الهدف من الدراسة: تحديد التغييرات التى تحدث فى الرنين المغناطيسى على الغدد اللعابية فى مرضى متلازمة سيككا المرتبطة بإلتهاب الكبد الويائى سى.

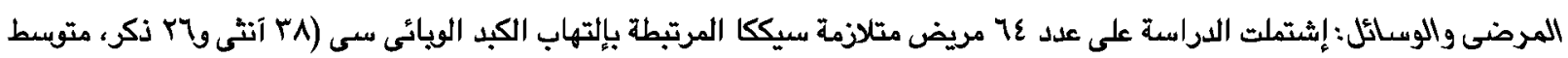

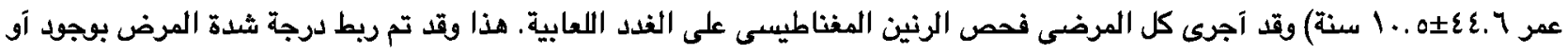

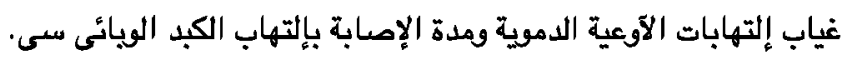

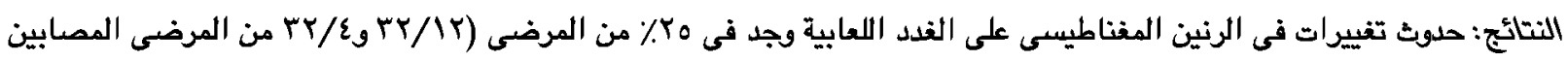

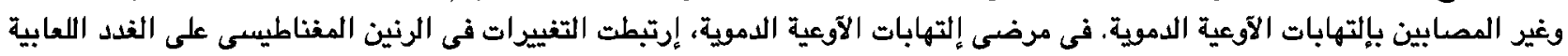
بمدة وشدة مرض إلتهابات الآومية الدموية. الإستستاج: فى مرضى إلتهابات الآوعية الدموية إرتبطت مدة وشدة المرض بحدوث تغييرات فى الرنين المغناطيسى على الغدد اللعابية. 